\title{
INTERAKSI MASYARAKAT SEKITAR DENGAN KAWASAN CAGAR ALAM DAN CAGAR ALAM LAUT PANGANDARAN
}

\author{
Interaction of Surrounding Communities with the Nature Reserve and Marine Nature \\ Reserves of Pangandaran
}

\section{Denni Susanto ${ }^{1}$, Lies Rahayu Wijayanti Faida ${ }^{2}$, Fahrina Risqi Hidayana Lubis ${ }^{2}$, Rizka Hanisaputra ${ }^{2}$}

\author{
${ }^{1}$ Prodi Pengelolaan Hutan, Sekolah Vokasi UGM, Yogyakarta \\ ${ }^{2}$ Fakultas Kehutanan, UGM, Yogyakarta
}

*Email: denni.s@ugm.ac.id

Direvisi: 23/06/2020, Diterbitkan: 01/08/2020

\begin{abstract}
Communities and conservation areas are two things that cannot be separated. Surrounding communities interact with conservation areas to fulfil their needs. This study aimed to know the forms of interaction between communities and the Nature Reserve and Marine Nature Reserve of Pangandaran as well as the factors that underlie these interactions. The method used in this study was a survey method with a total sample of 254 people. The target communities interviewed were communities of Pangandaran Village who carry out activities in Nature Reserve and Marine Nature Reserve of Pangandaran. The analysis used for data processing was descriptive analysis. The results showed that $44 \%$ of the community doing activities as fishermen, $17 \%$ renting out cruise ship services, $12 \%$ renting snorkeling equipment, $11 \%$ doing fishing activities, $6 \%$ as bagang fishermen and tour guides, and $4 \%$ as fishing fishermen. Factors underlying the interaction in Nature Reserve and Marine Nature Reserve of Pangandaran were community economic factors.
\end{abstract}

Keywords; Perception, interaction, community of forest, protected area

\begin{abstract}
ABSTRAK
Masyarakat dan kawasan konservasi merupakan dua hal yang tidak dapat dipisahkan. Masyarakat sekitar hutan melakukan interaksi dengan kawasan konservasi untuk memenuhi kebutuhannya. Penelitian ini bertujuan untuk mengetahui bentuk-bentuk interaksi yang dilakukan masyarakat Desa Pangandaran terhadap Cagar Alam dan Cagar Alam Laut Pangandaran, serta faktor-faktor yang mendasari interaksi tersebut. Metode yang digunakan pada penelitian ini adalah metode survey. Survei dilakukan dengan wawancara terhadap sebesar 254 orang masyarakat Desa Pangandaran yang melakukan kegiatan di CA dan CAL Pangandaran. Pengolahan data dilakukan dengan analisis deskriptif. Berdasarkan hasil penelitian bahwa interaksi yang dilakukan masyarakat adalah 44\% Masyarakat melakukan kegiatan sebagai nelayan, 17\% menyewakan jasa perahu pesiar, $12 \%$ menyewakan peralatan snorkelling, $11 \%$ melakukan kegiatan memancing, 6\% sebagai nelayan bagang dan pemandu wisata, serta $4 \%$ sebagai nelayan pancing. Faktor yang mendasari interaksi di CA dan CAL Pangandaran adalah faktor ekonomi masyarakat.
\end{abstract}

Kata kunci; Persepsi, interaksi, masyarakat hutan, kawasan konservasi 


\section{PENDAHULUAN}

Sumber daya alam merupakan komponen yang sangat penting bagi kehidupan manusia. Unsur-unsur yang terkandung di dalam sumber daya alam dibutuhkan manusia untuk memenuhi kebutuhan sehari-hari, salah satunya adalah sumber daya hutan. Saat ini, sumber daya hutan yang masih terjaga terdapat di kawasan konservasi (Sawitri, 2013). Pengelolaan kawasan konservasi sangat diperlukan untuk menjaga kelestarian sumber daya alam hayati yang ada di dalamnya. Masyarakat sekitar tidak dapat dipisahkan dalam pengelolaan sumber daya alam di kawasan konservasi, Hal ini karena hutan menjadi sumber pemenuhan kebutuhan seperti bernaung dan memanfaatkan hasil hutan kayu maupun non kayu (Fahmi, 2014).

Masyarakat sekitar kawasan konservasi merupakan bagian ekosistem yang selalu melakukan timbal balik dengan alam sekitar. Masyarakat dan lingkungan saling berinteraksi secara langsung di dalam sebuah sistem. Apabila masyarakat melakukan tindakan yang bersifat merusak, maka keberadaan manusia menjadi suatu ancaman bagi sumber daya alam (Sawitri, 2013). Interaksi yang terjadi antara masyarakat dengan kawasan konservasi berbeda-beda bentuknya. Hal ini dipengaruhi oleh persepsi atau pandangan masyarakat terhadap kawasan konservasi tersebut. Apabila persepsi masyarakat terhadap kawasan konservasi baik yaitu dengan menganggap kawasan konservasi berfungsi untuk melestarikan lingkungan, maka interaksi yang terjadi juga positif (Hangi, 2014). Sebagian besar kawasan konservasi menghadapi tekanan yang besar dari luar, seperti perambahan dan degradasi ekosistem. Di Indonesia, masalah sosial yang sangat berimplikasi dengan pengelolaan kawasan konservasi adalah tekanan terhadap sumber daya hutan karena adanya interaksi masyarakat dengan kawasan hutan (Hermawan, 2014). Cagar Alam (CA) dan Cagar Alam Laut (CAL) Pangandaran merupakan salah satu kawasan konservasi yang memiliki tekanan sosial tinggi karena berbatasan langsung dengan Desa Pangandaran.

CA dan CAL Pangandaran merupakan kawasan konservasi yang memiliki status paling tinggi. Tidak semua kegiatan di kawasan ini boleh dilakukan, termasuk kegiatan wisata. Kegiatan wisata yang dilakukan di cagar alam dapat memberikan ancaman bagi kelestarian kawasan yang akan mengakibatkan kerusakan ekosistem (Situmorang, 2014). Kegiatan wisata di CA dan CAL Pangandaran akan mengancam kelestarian Rafflesia patma yang merupakan tumbuhan langka dan juga dapat merusak terumbu karang yang ada di pantai. Oleh karena itu, pengelolaan kawasan hutan yang baik tidak hanya memperhatikan aspek teknis saja, tetapi juga memperhatikan aspek sosial dan budaya (Nurrochmat, 2005).

Keberdaaan masyarakat di kawasan CA dan CAL Pangandaran mengindikasikan bahwa sumber daya alam yang ada di kawasan tersebut sangat dibutuhkan oleh masyarakat sekitar. Hal ini dapat berdampak positif atau negatif bagi kawasan konservasi, tergantung dari interaksi yang dilakukan masyarakat. Oleh karena itu, penelitian ini dilakukan untuk mengetahui bentuk-bentuk interaksi yang dilakukan masyarakat sekitar CA dan CAL Pangandaran, serta faktor-faktor yang mendasari interaksi tersebut.

\section{METODE}

\section{Lokasi dan Waktu Penelitian}

Penelitian ini dilakukan di Desa Pangandaran, Kecamatan Pangandaran, Kabupaten Pangandaran, Jawa Barat. Selain di desa, pengambilan data juga dilakukan dengan observasi di lokasi kajian yaitu Cagar Alam Pangandaran dan Cagar Alam Laut Pangandaran. Kegiatan penelitian ini dilaksanakan pada bulan Juli sampai dengan Desember 2018. 


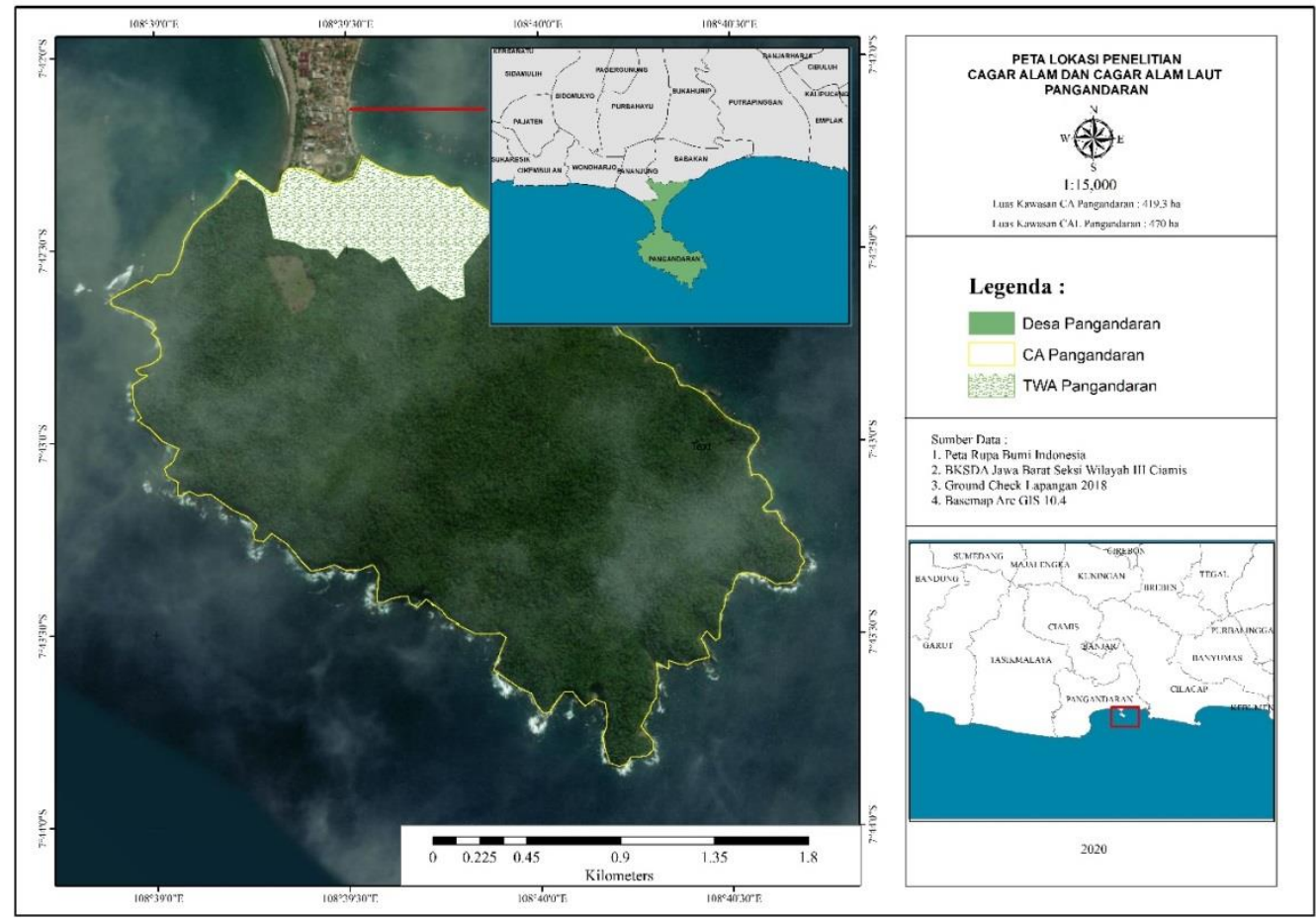

Gambar 1. Peta lokasi penelitian di Cagar Alam dan Cagar Alam Laut Pangandaran Figure 1. Map of research location in Nature Reserve and Marine Nature Reserve of Pangandaran

\section{Bahan dan Alat Penelitian}

Bahan dan alat yang digunakan pada penelitian ini adalah data profil desa dan masyarakat, peta CA dan CAL Pangandaran, GPS, alat tulis, kamera, voice recorder, dan panduan wawancara (interview guide).

\section{Prosedur Penelitian}

Penelitian ini dilakukan dengan menggunakan metode survei, yaitu dengan mendapatkan data dari tempat tertentu yang alamiah. Peneliti diharapkan melakukan perlakuan dalam pengumpulan data, seperti mengedarkan kuesioner, test, wawancara terstruktur dan sebagainya (Sugiyono, 2015). Penelitian dilakukan di Desa Pangandaran dan lokasi CA serta CAL Pangandaran. Jumlah sampel yang digunakan pada penelitian ini yaitu dengan menggunakan rumus Sugiyono (2015) sebagai berikut:

$$
n=\frac{X}{N} \times N 1
$$

\section{Keterangan:}

$n=$ jumlah sampel setiap dusun

$X=$ jumlah populasi setiap dusun

$N$ = jumlah populasi seluruhnya

$N 1$ = jumlah sampel seluruhnya

Berdasarkan profil desa, didapatkan total populasi seluruh dusun sebesar 3.532 orang. Sehingga, hasil perhitungan didapatkan sampel sebesar 254 orang. Selain melakukan wawancara di desa, peneliti juga melakukan observasi dan mewawancarai masyarakat yang melakukan aktivitas di CA dan CAL Pangandaran. 


\section{Analisis Data}

Analisis data yang diguanakan pada penelitian ini adalah deskriptif, yaitu dengan mengolah data lapangan dan mereduksinya sehingga didapatkan hasil data sesuai dengan kebutuhan. Data yang didapatkan juga disajikan dengan bentuk tabulasi silang menggunakan persentase. Tabulasi silang digunakan untuk mendapatkan hubungan antar variabel yang diolah.

\section{HASIL dan PEMBAHASAN,}

\section{A. Karakteristik Masyarakat}

Karakteristik masyarakat merupakan parameter pada kehidupan masyarakat yang didapatkan dari profil responden masyarakat Desa Pangandaran. Karakteristik masyarakat atau profil responden yang diambil pada penelitian ini meliputi : umur, tingkat pendidikan, jenis kelamin, dan jenis pekerjaan. Berikut merupakan prosentase profil responden Desa Pangandaran.

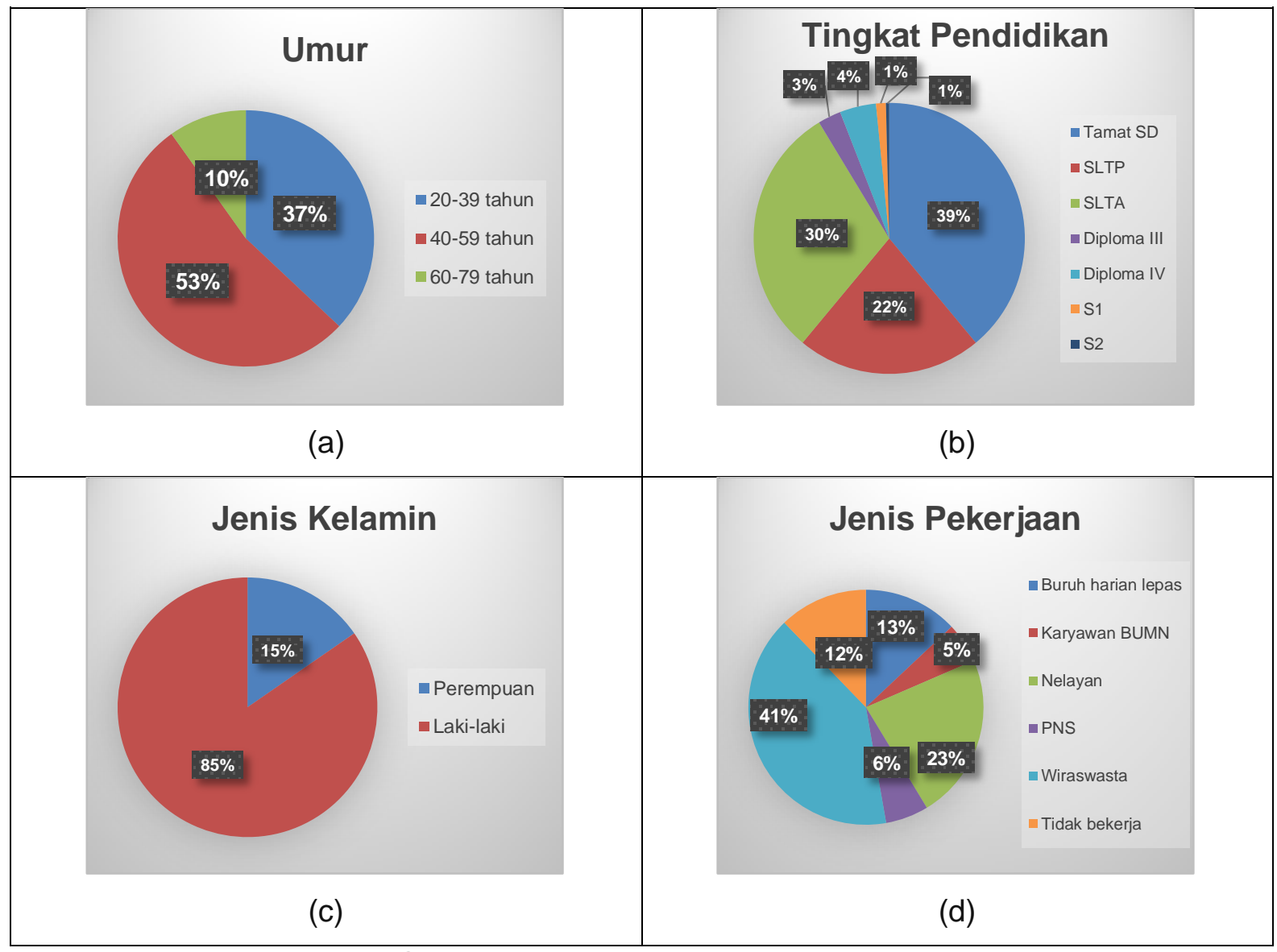

Gambar 2. Persentase profil responden

Figure 2. Percentage of respondent profile

Karakteristik masyarakat Desa Pangandaran berdasarkan profil responden digolongkan menjadi 3 kelas umur, dengan rentan umur paling banyak yaitu 40 tahun sampai dengan 59 tahun. Pada tingkat pendidikan masyarakat, mayoritas masyarakat sudah perpendidikan tinggi yaitu Diploma IV sebanyak 39\%, SLTA 30\%, dan SLTP $22 \%$. Masyarakat desa yang menjadi responden paling banyak berjenis kelamin pria yaitu $85 \%$, hal ini dikarenakan mayoritas masyarakat yang melakukan aktivitas di dalam kawasan CA dan CAL adalah berjenis kelamin pria. Hal ini tidak dapat dilepaskan dengan jenis pekerjaan masyarakat sekitar, dimana sebanyak $23 \%$ masyarakat desa bekerja sebagai nelayan yang 
secara umum merupakan pekerjaan yang dilakukan masyarakat berjenis kelamin pria. Karakteristik masyarakat Desa Pangandaran menentukan cara pandang masyarakat terhadap kawasan CA dan CAL Pangandaran. Hal ini akan mempengaruhi aktivitas masyarakat pada kawasan CA dan CAL Pangandaran. Karakteristik masyarakat seperti umur dan tingkat pendidikan mempengaruhi cara pandang atau persepsi seseorang terhadap suatu objek (Yuwono, 2006).

\section{B. Bentuk-bentuk Interaksi Masyarakat}

Masyarakat Desa Pangandaran merupakan masyarakat yang paling banyak melakukan kegiatan di CA dan CAL Pandandaran. Hal ini terjadi karena Desa Pangandaran merupakan desa yang paling dekat dengan kawasan tersebut. Terdapat beberapa aktivitas masyarakat di kawasan CA dan CAL yang tergolong interaksi yang dilakukan masyarakat Desa Pangandaran, diantaranya sebagai pemandu wisata, sebagai nelayan, memancing, jasa penyewaan perahu, jasa penyewaan peralatan snorkelling. Kegiatan-kegiatan tersebut dilakukan masyarakat untuk memenuhi kebutuhan sehari-hari. Kegiatan yang dilakukan masyarakat paling banyak adalah sebagai nelayan dan sebagai jasa penyewaan perahu. Hal ini dikarenakan wilayah Pangandaran merupakan wilayah pesisir yang kaya akan hasil laut, termasuk kawasan CAL Pangandaran. Berikut merupakan persentase interaksi yang dilakukan masyarakat sekitar terhadap CA dan CAL Pangandaran.

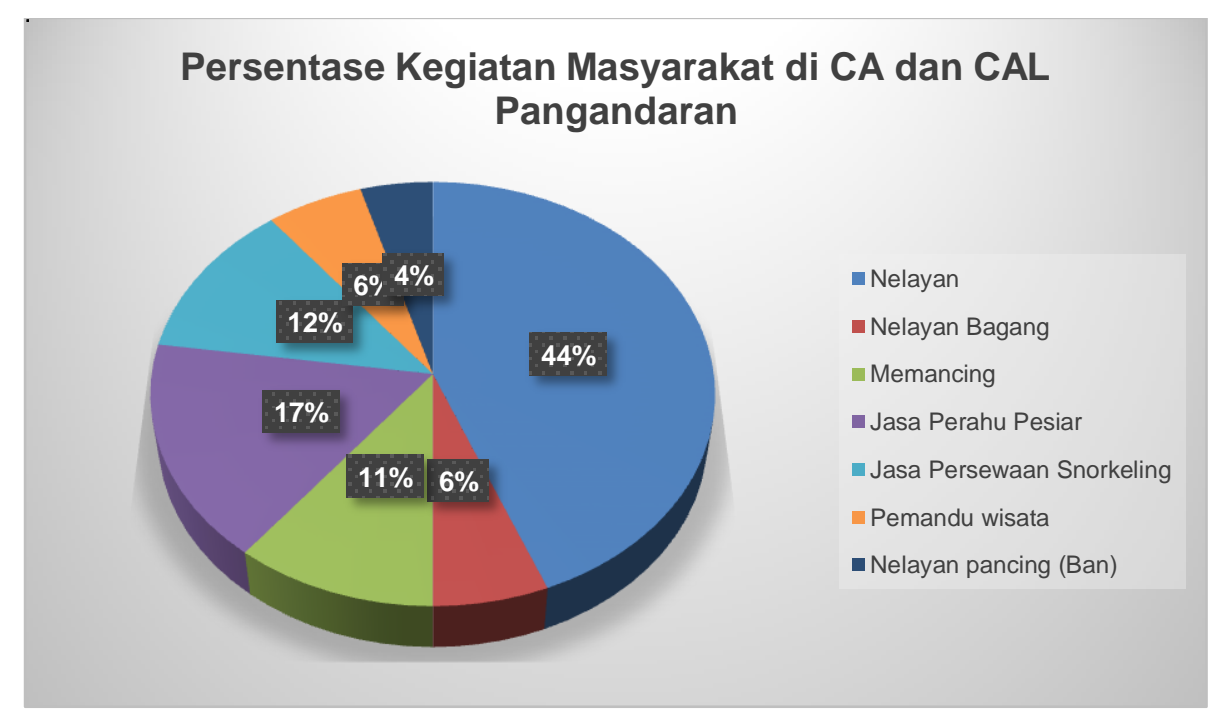

Gambar 3. Persentase kegiatan masyarakat di CA dan CAL Pangandaran Figure 3. Percentage of community activities in CA and CAL Pangandaran

Berdasarkan Gambar 3, terdapat 7 interaksi masyarakat Desa Pangandaran terhadap kawasan CA dan CAL Pangandaran. 44\% Masyarakat melakukan kegiatan sebagai nelayan, $17 \%$ menyewakan jasa perahu pesiar, $12 \%$ menyewakan peralatan snorkelling, $11 \%$ melakukan kegiatan memancing, $6 \%$ sebagai nelayan bagang dan pemandu wisata, serta 4\% sebagai nelayan pancing sekitar CAL Pangandaran. Masyarakat yang lama tinggal dan menetap di sekitar kawasan konservasi akan memiliki keterikatan dengan daerah yang ditempati dan terhadap sumber daya alam sekitar (Wijaksono, 2013). Dampak yang diberikanpun dapat negatif maupun positif. Hal ini dapat memunculkan rasa memiliki yang mendalam (Hamid, 2011).

Dampak positif yang diberikan dari interaksi yang dilakukan masyarakat sekitar adalah masyarakat sekitar merasa memiliki kawasan CA dan CAL, sehingga akan memunculkan rasa ingin menjaga dan melindungi kawasan supaya tidak rusak. Masyarakat melakukan tindakan tersebut agar sumber pendapatan mereka tidak rusak atau hilang. 
Sedangkan dampak negatif dari adanya interaksi tersebut adalah rusaknya keanekaragaman ekosistem seperti terumbu karang karena alat pancing bagang, sampah dari kegiatan wisata juga akan menurunkan fungsi lingkungan, dan juga akibat kegiatan snorkeling dapat merusak padang lamun dan ekosistem perairan. Anacaman terhadap kawasan konservasi terkait keanekaragaman hayati secara tidak langsung akan mengancam populasi manusia di sekitar, hal ini dikarenakan manusia dan lingkungan saling berinteraksi (Indrawan, 2007).
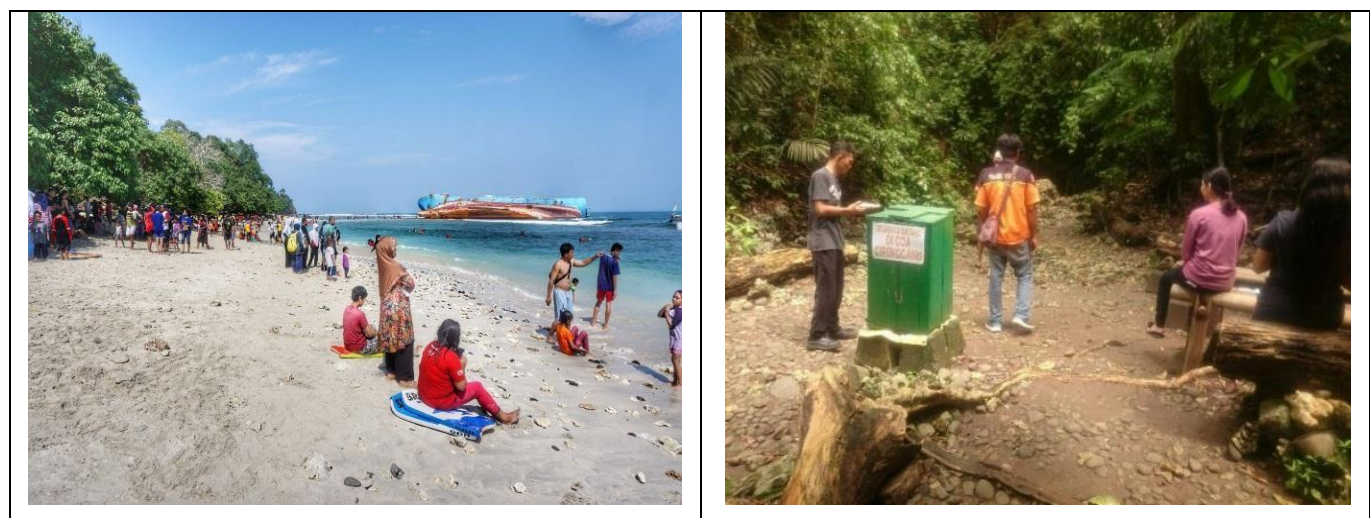

Gambar 4. Masyarakat yang melakukan kegiatan di lokasi Pantai Pasir Putih (kiri) dan Gua Rengganis (kanan) yang merupakan lokasi CA Pangandaran

Figure 4. Communitiy who conducting activities at Pasir Putih Beach (left) and Rengganis Cave (right) which are the locations of CA Pangandaran

\section{Persepsi Masyarakat Terhadap Fungsi Kawasan}

CA dan CAL Pangandaran merupakan kawasan konservasi yang memiliki status tertinggi, tidak semua kegiatan dapat dilakukan di lokasi tersebut. Berdasarkan data hasil wawancara, $46 \%$ masyarakat masih menganggap cagar alam berfungsi sebagai tempat wisata. Sedangkan yang menganggap CA Pangandaran sebagai tempat perlindungan flora dan fauna sebesar 35,04\%, 8,66\% lainnya menganggap fungsinya sebagai tempat pelestarian kawasan, dan sisanya sebagai tempat penelitian. Sedangkan hanya $0,39 \%$ masyarakat yang menganggap CAL Pangandaran sebagai kawasan pelestarian alam. Tabel persepsi masyarakat terhadap fungsi kawasan CA dan CAL Pangandaran disajikan pada Tabel 1.

Tabel 1. Persepsi masyarakat tentang fungsi CA dan CAL Pangandaran Table 1. Community perception about function of CA and CAL Pangandaran

\begin{tabular}{lccccc}
\hline \multicolumn{1}{c}{ Kategori kawasan } & \multicolumn{5}{c}{ Fungsi Kawasan } \\
\cline { 2 - 6 } & Wisata & Penelitian & $\begin{array}{c}\text { Perlindungan flora } \\
\text { dan fauna }\end{array}$ & $\begin{array}{c}\text { Pelestarian } \\
\text { kawasan }\end{array}$ & Jumlah \\
\hline Cagar Alam & $46,46 \%$ & $0,39 \%$ & $35,04 \%$ & $8,66 \%$ & $90,55 \%$ \\
Gunung Pananjung & $3,94 \%$ & $0 \%$ & $2,36 \%$ & $2,36 \%$ & $8,66 \%$ \\
Hutan Wisata ALam & $0,39 \%$ & $0 \%$ & $0 \%$ & $0 \%$ & $0,39 \%$ \\
Cagar Alam Laut & $0 \%$ & $0 \%$ & $0 \%$ & $0,39 \%$ & $0,39 \%$ \\
Jumlah & $50,79 \%$ & $0,39 \%$ & $37,40 \%$ & $11,42 \%$ & $100 \%$ \\
\hline
\end{tabular}

Sumber : Analisis Data, 2019

Berdasarkan tabel 1, pengetahuan masyarakat akan fungsi dari CA dan CAL perlu ditingkatkan dengan sosialisasi atau menambah papan informasi terkait fungsi kawasan tersebut. Secara umum pekerjaan masyarakat Desa Pangandaran adalah sebagai pemandu 
wisata di Kawasan Taman Wisata Alam (TWA) Pangandaran, akan tetapi batas Cagar Alam dan TWA Pangandaran yang tidak begitu jelas membuat masyarakat mengganggap CA Pangandaran sama dengan TWA Pangandaran. Lokasi Pantai Pasir Putih dan Gua Rengganis yang merupakan kawasan CA banyak dikunjungi masyarakat karena dianggap sebagai lokasi wisata (Gambar 2). Persepsi yang ditunjukkan masyarakat Desa Pangandaran dipengaruhi oleh kondisi lingkungan seperti jenis pekerjaan (Arifin, 2011). Mengetahui persepsi masyarakat tentang CA dan CAL Pangandaran, membuat pengelola lebih mudah untuk merancang strategi konservasi dalam pengelolaan kawasan konservasi, sehingga lebih efektif dalam mengakomodir kebutuhan masyarakat dengan tetap menjaga kelestarian sumber daya hutan (Dolisca, 2007).

\section{Faktor-faktor yang Mempengaruhi Interaksi}

Interaksi yang bersifat merusak yang dilakukan oleh masyarakat seperti nelayan bagang dan memancing merupakan interaksi yang dilakukan di CAL Pangandaran. Kawasan CAL yang posisinya mengililingi CA dan TWA Pangandaran memang tidak dapat dihindarkan dari aktivitas masyarakat dan pengunjung. Sumber pendapatan utama dari sektor laut membuat interaksi mayarakat dan kawasan CAL terjadi dari sebelum ditetapkannya kawasan CA dan CAL Pangandaran. Interaksi masyarakat dipengaruhi oleh tingkat pendapatan, dalam memenuhi kebutuhannya, masyarakat akan meningkatkan interaksinya terhadap sumber daya hutan secara maksimal (Kristin, 2018).

CA dan CAL Pangandaran memiliki fungsi yang sangat besar bagi kehidupan masyarakat sekitar. Ca dan CAL Pangandaran secara langsung memiliki manfaat kepada masyarakat seperti keanekaragaman hayati yang dimanfaatkan untuk ekonomi, ekologi, dan sosial budaya. Interaksi yang dilakukan masyarakat dari aspek ekonomi akan meningkatkan pendapatan masyarakat sekitar, selain itu dari aspek sosial juga akan memberikan nilai yang besar dalam tatanan bermasyarakat (Neil, 2006). Faktor perekonomian merupakan faktor utama yang mendasari interaksi yang dilakukan masyarakat terhadap CA dan CAL Pangandaran. Sebagian besar pendapatan masyarakat diperoleh dari kawasan, mulai dari pemandu wisata sampai dengan hasil laut. Hal ini membuat pengelola CA dan CAL Pangandaran harus mempertimbangkan aspek sosial ekonomi dalam merancang strategi pengelolaan sumber daya hutan di kawasan. Dalam mengelola sumber daya hutan, masyarakat harus dilibatkan agar kelestarian alam tetap terjaga, walaupun dalam tekanan sosial yang tinggi (Dedi, 2015).

\section{KESIMPULAN dan SARAN}

Kesimpulan dari penelitian ini adalah bentuk-bentuk interaksi masyarakat yang dilakukan di Cagar Alam dan Cagar Alam Laut Pangandaran meliputi : pengambilan ikan (nelayan), menyewakan jasa perahu pesiar, menyewakan peralatan snorkelling, melakukan kegiatan memancing, sebagai nelayan bagang dan pemandu wisata, serta sebagai nelayan pancing. Sedangkan Faktor utama yang mendasari interaksi masyarakat adalah faktor ekonomi.

Saran yang diusulkan pada penelitian ini adalah dalam pengelolaan kawasan konservasi khususnya CA dan CAL Pangandaran sebaiknya melibatkan masyarakat. Hal ini untuk untuk menjaga kelestarian sumber daya hutan dan juga meningkatkan nilai ekonomi masyarakat.

\section{UCAPAN TERIMA KASIH}

Penulis mengucapkan terima kasih kepada Universitas Gadjah Mada terutama Prodi Pengelolaan Hutan sebagai afiliasi penulis. Selain itu penulis juga mengucapkan terima kasih kepada Fahrina Risqi dan Rizka Hanisaputra mahasiswa Fakultas Kehutanan yang 
telah membantu dalam pengambilan dan Kepala Resort Cagar Alam Pangandaran yang telah membantu dalam menyediakan data pendukung, sehingga penelitian ini dapat selesai dengan optimal.

\section{DAFTAR PUSTAKA}

Arifin, Z. (2011). Penelitian Metode dan Paradigma Baru. Bandung: Remaja Rosdakarya.

Dedi, W., Surachman, M., \& Fahrizal. (2015). Analisis Pendapatan Masyarakat Dalam Pemanfaatan Hutan Tembayang Di Dusun Kurnia Kecamatan Kuala Behe Kabupaten Landak. Jurnal Hutan Lestari, 3 (1) 58-64.

Dolisca, F., McDaniel, J. M., \& Teeter, L. D. (2007). Farmers' perceptions toward forest: A case study from Haiti. Forest Policy \& Economics, 9 (6) : 704-712.

Fahmi, Agus, P., \& Dodi, S. (2014). Interaksi dan Pemanafaatan Hasil Hutan oleh Masyarakat Sekitar Taman Nasional Gunung Leuser. Peronema Forestry Science Journal, 4 (3).

Hamid, R., Zulkarnaini, \& Saam, Z. (2011). Analisis Sosial Ekonomi Masyarakat Desa Hutan Pasca Kegiatan HPH PT. Siak Raya Timber Di Kabupaten Pelalawan, Provinsi Riau. Jurnal Ilmu Lingkungan, 2 (5).

Hangi, A., Rizalinda, \& Irwan , L. (2014). Pengetahuan dan Persepsi Masyarakat Terhadap Cagar Alam Raya Pasi Kota Singkawang. Jurnal Protobion, 3 (2) : 125-134.

Hermawan, M. T., Faida, L. R., Wianti, K. F., Marhaento, H., \& Anindia, A. (2014). Pengelolaan Kawasan Konservasi. Yogyakarta: Gadjah Mada University Press.

Idrus, M. (2009). Metode Penelitian IImu Sosial. Yogyakarta: Erlangga.

Indrawan, M., Richard, B. P., \& supriatna, J. (2007). Biologi Konservasi. Jakarta: Yayasan Obor Indonesia.

Kristin, Y., Rommy , Q., \& Hari, K. (2018). Interaksi Masyarakat Sekitar Hutan Terhadap Pemanfaatan Lahan Taman Hutan Raya Wan Abdul Rachman. Jurnal Sylva Lestari, $6(3): 1-8$.

Neil, A., Golar, \& Hamzari. (2016). Analisis Ketergantungan Mastarakat Terhadap Hasil Hutan Bukan Kayu Pada Taman Nasional Lore Lindu (Studi Kasus Desa Sidodo I Kecamatan Biromaru dan Desa Pakuli Kecamatan Gumbusa). e-Jurnal Mitra Sains, 4 (1): 29-39.

Nurrochmat, D. R. (2005). Strategi Pengelolaan Hutan, Upaya Menyelamatkan Rimba yang Tersisa. Yogyakarta: Pustaka Pelajar.

Sawitri. (2013). Persepsi Masyarakat Terhadap Restorasi Zona Rehabilitasi di Taman Nasional Gunung Gede Pangrango. Indonesian Forest Rehabilitation Journal, 1 (1) : 92.

Situmorang, Y. K. (2014). Pemanfaatan Cagar Alam Pulau Sempu Kabupaten Malang Ditinjau dari Pasal 33 Peraturan Pemerintah No.28 Tahun 2011 Tentang Pengelolaan Suaka Alam dan Pelestarian Alam. Malang: Universitas Brawijaya .

Sugiyono. (2015). Metode Penelitian Kuantitatif, Kualitatif, dan R\&D. Bandung: Alvabeta.

Undang-Undang No. 5 Tahun 1990. Konservasi Sumberdaya Alam Hayati dan Ekosistemnya. Jakarta: Sekretariat Negara.

Wijaksono, S. (2013). Pengaruh Lama Tinggal Terhadap Tingkat Partisipasi Masyarakat Dalam Pengelolaan Lingkungan Permukiman. Jurnal ComTech, 24-32.

Yuwono. (2006). Persepsi dan Partisipasi Masyarakat Terhadap Pembangunan Hutan Rakyat Pola Kemitraan di Kabupaten Musi Rawas Sumatera Selatan. Tesis Program Studi Pengelolaan Sumberdaya Alam dan Lingkungan. Bogor: Sekolah Pascasarjana Institut Pertanian Bogor. 